\title{
Binding of Al(III) to synthetic RNA. Metal-mediated strand aggregation
}

Matteo Lari, ${ }^{a}$ Tarita Biver, ${ }^{b}$ Natalia Busto, ${ }^{a}$ Héctor J. Lozano, ${ }^{a}$ José M. Leal, ${ }^{a}$

Fernando Secco ${ }^{\mathrm{b}}$ and Begoña García*a

${ }^{a}$ Departamento de Química, Universidad de Burgos, Plaza Misael Bañuelos s/n, 09001 Burgos, Spain.E-mail:begar@ubu.es

${ }^{b}$ Dipartimento di Chimica e Chimica Industriale, Università di Pisa, Via Moruzzi 13, 56124 Pisa, Italy

Over the last years, focused interest in aluminum has been heightened by recent studies regarding its health effects. The possible relationship with chronic diseases makes it convenient to address more in depth the aluminum reactivity with biologically relevant molecules. The present work investigates the mechanism of action of aluminum ion towards RNA through a detailed thermodynamic and kinetic study of their interaction. Trivalent aluminum ion was stabilized in solution by complexation with cacodylate anion, even at neutral $\mathrm{pH}$, so that the study with biological molecules can be feasible. The results obtained with spectrophotometry, circular dichroism, viscometry and thermal stability measurements indicate that aluminum strongly interacts with single and duplex RNA structures. The reaction mechanisms determined from the kinetic data indicate that cacodylate inhibits the reaction of aluminum with RNA; is spite of that, this species is necessary to keep the metal in solution. Notably, further interaction occurred under excess of aluminum, inducing the aggregation of single-stranded RNAs. The kinetic treatment by the Avrami equation has demonstrated that the difference found for formation of RNA aggregates can be ascribed to the polynucleotide secondary structures. The observed stabilization of multiple-stranded systems can be of interest for the use of aluminum in the study of non-canonical nucleic acid structures.

\section{Introduction}

In biological environments nucleic acids are surrounded by metal ions. Metal cations play an essential role in the secondary DNA and RNA structures. Numerous studies on the effect of mono- and divalent metal ions abound in the scientific literature, and different attempts to rationalize their behaviour have been made. ${ }^{1,2}$ Metal cations can bind to monomer units of the chain through two coordination sites: (i) the phosphate group (the main coordination site of mono- and divalent cations of Groups I and XII) ${ }^{3-6}$ (ii) the nitrogenous bases (main site for transition divalent metal ions)..$^{3-7}$ In addition, such ions can interact through more than one reaction site, forming chelate (phosphate-phosphate) and macrochelate (nitrogenous base-phosphate) adducts. ${ }^{2}$ Moreover, it has been verified that metal ions can stabilize non-canonical forms of DNA and RNA. ${ }^{8}$

On the other hand, thermodynamic and kinetic studies of trivalent metal ions with nucleic acids are rather scarce, possibly due to their complex behaviour in aqueous solution (e.g. hydrolysis processes) ${ }^{9}$. In particular, only few articles on the reactivity of aluminum with polynucleotides have been published. ${ }^{10,11}$ In these studies the effect 
of aluminum ions was tested only for low metal concentrations, i.e. low metal/DNA ratio; moreover, possible interactions of aluminum with anionic ligands present in the reaction medium were disregarded. ${ }^{12}$

Concerning biological effects, the hexahydrated and hydroxylic aluminum forms are toxic in nature ${ }^{13-15}$ and can affect human organs such as liver, heart and kidney. ${ }^{16-18} \mathrm{In}$ addition, aluminum is believed to be responsible for health diseases such as Alzheimer and Parkinson, ${ }^{19,20}$ even though no overall agreement could be found so far. $^{21}$ Lastly, increasing interest has been addressed in the last years towards aluminum for its possible relationship with breast cancer because of its use as antiperspirant agent in underarm cosmetics. ${ }^{22-24}$ Inside the cell, its bioavailability is significantly reduced not only because of precipitation, but also due to complexation with oxygenated functional groups present in biological molecules. ${ }^{25-27}$ Despite all this, free aluminum can interact with the cell membrane and enter the cell. ${ }^{28}$

Recently, it has been discovered in our laboratories that dimethylarsinate anion (also known as cacodylate) is able to prevent precipitation of $\mathrm{Al}(\mathrm{III})$ even at $\mathrm{pH} 7$ due to formation of a complex species, which has been characterized. ${ }^{29}$ This finding has enabled us to investigate the interaction of $\mathrm{Al}$ (III) with nucleic acids, also at neutral $\mathrm{pH}$, where uncomplexed $\mathrm{Al}(\mathrm{III})$ is insoluble.

We present here a study of the interaction of aluminum with synthetic RNAs, namely, the poly-riboadenylic (poly(rA)) and the poly-ribouridylic (poly(rU)) acids, at $\mathrm{pH} 5.0$ and 7.0. Neutral $\mathrm{pH}$ was chosen for mimicking biological conditions, whereas $\mathrm{pH}=5.0$ was taken into account to observe the effect of aluminum on $[\operatorname{poly}(\mathrm{rA})]_{2}$, the double-stranded form of poly(rA), which forms at this acidity level. ${ }^{30}$

\section{Experimental}

\subsection{Materials}

The aluminum(III) source was provided by the octahydrate perchlorate $\left(\mathrm{Al}\left(\mathrm{ClO}_{4}\right)_{3} \cdot 8 \mathrm{H}_{2} \mathrm{O}\right)$ from Fluka. The stock solutions were prepared in doubly distilled water, adding $\mathrm{HClO}_{4}$ acid up to $\mathrm{pH}=2.0$ to avoid precipitation. Standardization of aluminum stock solutions was attained by EDTA titrations, using Eriochrome Black$\mathrm{T}$ as an indicator. The titration was carried out by adding a known EDTA excess to an aluminum aliquot. The solution was boiled and acetate buffer was added to achieve $\mathrm{pH}=6.0$. Afterwards, the solution was titrated with a standardized $\mathrm{Zn}^{2+}$ solution to obtain the analytical concentration of aluminum, $\mathrm{C}_{\mathrm{Al}}$. Sodium dimethylarsinate (NaCac, 96\%) was purchased from Carlo Erba and stock solutions were prepared in doubly distilled water, $\mathrm{C}_{\mathrm{L}}$ being its analytical concentration.

Working solutions of the aluminum/cacodylate complex were prepared from stock solutions adding doubly distilled water, which was used as reaction medium. Ionic strength was kept at $0.1 \mathrm{M}$ with sodium perchlorate monohydrate salt (Merck), while the desired $\mathrm{pH}$ was attained by addition of calibrated amounts of $\mathrm{NaOH}$ and $\mathrm{HClO}_{4}$. Adenosine 5'-monophosphate monohydrate (AMP), poly-riboadenylic (poly(rA)) and poly-ribouridylic (poly(rU)) acids were purchased from Sigma as potassium salts and the relevant stock solutions were prepared by dissolving suitable amounts of the solid in water. Standardization of the RNA stock solutions was attained spectrophotometrically to $\varepsilon_{257}=10100 \mathrm{M}^{-1} \mathrm{~cm}^{-1}$ for poly $(\mathrm{rA})$ and $\varepsilon_{260}=8900 \mathrm{M}^{-1} \mathrm{~cm}^{-1}$ for 
poly $(\mathrm{rU})$, at $\mathrm{I}=0.1 \mathrm{M}(\mathrm{NaCl}), \mathrm{pH}=7.0(\mathrm{NaCac})$ and $\mathrm{T}=25.0^{\circ} \mathrm{C}$. The analytical concentration of polynucleotides, $\mathrm{C}_{\mathrm{P}}$, was expressed as the concentration of the phosphate group for single-stranded forms and as the concentration of base pairs for poly(rA) when it is present as double-helix $(\mathrm{pH}=5)$. In fact, poly(rA) becomes $[\text { poly(rA) }]_{2}$ at acidic $\mathrm{pH}^{30,31}$

\subsection{Methods}

pH-meter. The $\mathrm{pH}$ value was controlled by means of a Metrohm 713 (Herisau, Switzerland) $\mathrm{pH}$-meter, with a combined glass electrode (precision of the $\mathrm{pH}$ solution was \pm 0.1 . Nine buffers in the 1.7-12.5 $\mathrm{pH}$ range were required for a proper calibration of the $\mathrm{pH}$-meter.

Light Scattering Test. Scattering of the solutions was evaluated using a LS55 Luminescence Spectrometer (Perkin Elmer), selecting $\lambda_{\mathrm{ex}}=\lambda_{\mathrm{em}}=250 \mathrm{~nm}$ and recording the absolute value of the Rayleigh scattering peak. Light scattering proofs for solutions of different $\mathrm{C}_{\mathrm{L}} / \mathrm{C}_{\mathrm{Al}}$ ratios were carried out after one day equilibration, at $\mathrm{pH}=5.0$ and $\mathrm{pH}=7.0$.

Nuclear Magnetic Resonance. Monodimensional ${ }^{1} \mathrm{H}-\mathrm{NMR},{ }^{31} \mathrm{P}-\mathrm{NMR}$ and ${ }^{27} \mathrm{Al}-$ NMR spectra were acquired at $25^{\circ} \mathrm{C}$ with a Varian Unity Inova-400 $(399.94 \mathrm{MHz}$ for ${ }^{1} \mathrm{H}, 161.9 \mathrm{MHz}$ for ${ }^{31} \mathrm{P}$ and $104.21 \mathrm{MHz}$ for ${ }^{27} \mathrm{Al}$ ) spectrometer. 1D ${ }^{1} \mathrm{H}-\mathrm{NMR}$ spectra were recorded with 32 scans into $32 \mathrm{k}$ data points over $16 \mathrm{ppm}$ spectral width. ${ }^{1} \mathrm{H}$ chemical shifts were referenced internally to TMS using 1,4-dioxane in $\mathrm{D}_{2} \mathrm{O}$ $(\delta=3.75 \mathrm{ppm})$. The NMR data were analysed with the MestReNova version 6.1.1 program.

UV Spectroscopy. Spectrophotometric titrations and kinetic studies were carried out with a double-beam 2450-Spectrophotometer (Shimadzu). Regarding titrations, increasing aliquots of a $\mathrm{Al} / \mathrm{Cac}$ complex solution were added to a cuvette containing the polynucleotide. The spectra were recorded after the equilibrium had been reached. Kinetic studies were carried out by adding a defined concentration of $\mathrm{Al} / \mathrm{Cac}$ complex to a cuvette containing the RNA, and absorbance versus time curves were acquired. Kinetic experiments were performed by changing the concentration of the aluminum/cacodylate species, cacodylate ligand and RNA. The initial rate method was used to estimate the reaction order with respect to each reactant.

Thermal Stability. Denaturation tests were performed with the Shimadzu spectrophotometer, recording one spectral curve every $5{ }^{\circ} \mathrm{C}$ and waiting for signal stabilization $(20 \mathrm{~min})$. Solutions at different metal complex-to-RNA ratios were analyzed to observe the possible destabilization/stabilization of the double or multiple-stranded structures.

Circular Dichroism. Circular dichroic spectra were recorded with a MOS 450 equipment (BioLogic, Science Instruments) coupled with a water thermostat $\left(25.0 \pm 0.1{ }^{\circ} \mathrm{C}\right)$. The thermodynamic study was carried out using different solutions at different metal complex-RNA ratios, once the solutions had reached the equilibrium, in a $1 \mathrm{~cm}$ path-length cell. The spectra were recorded in the $200-400 \mathrm{~nm}$ range, with a scan rate of $0.5 \mathrm{~nm} / \mathrm{s}$. Kinetic data were obtained by acquiring the evolution with time of the dichroic signal at a defined wavelength. Changes in the circular dichroism spectra of the polynucleotides are related to variations of their secondary structure. In 
particular, a correlation between the intensity of the dichroic peaks and the stacking interaction has been established. ${ }^{32}$ Single-stranded poly(rA) exhibits a partially ordered structure, while poly(rU) displays a random coil geometry, affecting the intensity of the dichroic signal.

Viscometry. An Ubbelhode microviscometer was used to study the nucleic acid viscosity at different aluminum complex-RNA ratios. The temperature was kept at $25.0^{\circ} \mathrm{C}$ by a water thermostat. The variation of the viscosity of polynucleotides can be related to modifications of their structure, the viscosity being associated to nucleic acid elongation (Equation (1)), ${ }^{33}$

where $[\eta]$ and $\left[\eta_{0}\right]$ are the viscosities of the bound and free polynucleotide, respectively, and $t, t_{0}$ and $t_{s}$ denote the efflux times of the bound RNA, the free RNA and the solvent, respectively.

\section{Results and Discussion}

Firstly, we characterized the aluminum/cacodylate complex, its solubility and stability at $\mathrm{pH} 5.0$ and 7.0 and then we addressed our attention to the interaction of the complex with the RNAs.

\subsection{Properties of aluminum/cacodylate system at $\mathbf{p H} 5.0$ and 7.0}

In a previous study of the $\mathrm{Al} / \mathrm{Cac}$ system, we found that in $1: 1 \mathrm{Al}: \mathrm{Cac}$ ratio and at $\mathrm{pH}=5.0$, the $\mathrm{Al}_{2} \mathrm{Cac}$ dimeric form is the major species present in solution, accompanied by minor amounts of the $\mathrm{Al}_{2} \mathrm{Cac}_{2}$ dimer, whereas at $\mathrm{pH}=7.0$ formation of remarkable amounts of a $\mathrm{Al}_{13}$ oligomer is visualized. ${ }^{29}$ However, further tests aimed to individuate optimal ligand distribution and concentration for the present study were carried out here.

At $\mathrm{pH}=5.0$ no light scattering of aluminum/cacodylate solutions was detected for all the investigated values of the cacodylate concentration, $\mathrm{C}_{\mathrm{L}}$ (Fig. 1A ESI, Supporting Information). This finding indicated that neither precipitation nor reactant aggregation occurred. However, at $\mathrm{pH}=7.0$ scattering was found (Fig. 1B ESI). The higher the cacodylate concentration, the lower the light dispersion, until the scattering disappeared for cacodylate/aluminum $=\mathrm{C}_{\mathrm{L}} / \mathrm{C}_{\mathrm{Al}}=5$.

The ${ }^{1} \mathrm{H}-\mathrm{NMR}$ study performed at $\mathrm{pH}=7.0$ agrees with the scattering measurements. Actually, the signals of the aluminum/cacodylate complexes increased with the concentration of cacodylate (Fig. 2A ESI). As the largest peaks in the ${ }^{1} \mathrm{H}-\mathrm{NMR}$ spectra had the same chemical shift as the ones found for the aluminum/cacodylate dimeric forms at $\mathrm{pH}=5.0,{ }^{29}$ we assumed that the main Aluminum containing species, at $\mathrm{pH}=7.0$ and in the presence of an excess of cacodylate, are dimeric in nature. Therefore, it follows that an excess of cacodylate promotes the disaggregation of the $\mathrm{Al}_{13}$ oligomer, forming simpler species. Similar behaviour has been observed for other oxygen functionalized ligands. ${ }^{34}$ The extent of complex formation reached a plateau at about $\mathrm{C}_{\mathrm{L}} / \mathrm{C}_{\mathrm{Al}}=5.0$, in agreement with the light scattering experiments (see Fig. 2B ESI).

Based on the above results, the $C_{\mathrm{L}} / \mathrm{C}_{\mathrm{Al}}=5.0$ ratio was kept for all experiments in the presence of mono and polynucleotides to maintain the same experimental conditions. 
This ratio was increased only for the kinetic experiments where $C_{L}$ was varied. It is reasonable to assume that, under conditions of cacodylate excess, the concentration of $\mathrm{Al}_{2} \mathrm{Cac}_{2}\left(\mathrm{M}_{2} \mathrm{~L}_{2}\right)$ will be higher compared to the conditions of the previous work, where $\mathrm{C}_{\mathrm{L}} / \mathrm{C}_{\mathrm{Al}}=1.0$. Actually, the kinetic study (see below) has provided evidence for the presence of remarkable amounts of the above dimer. From now on, the analytical concentration of the $\mathrm{Al} / \mathrm{Cac}$ complex will be termed $\mathrm{C}_{\mathrm{AlCac}}$.

\subsection{Binding of $\mathrm{Al} / \mathrm{Cac}$ to riboadenosine monophosphate (AMP)}

${ }^{1} \mathrm{H},{ }^{31} \mathrm{P}$ and ${ }^{27} \mathrm{Al}-\mathrm{NMR}$ spectra were recorded for the Al/Cac-AMP system (1:1) at $\mathrm{pH}$ 5.0 and 7.0. At $\mathrm{pH}=5.0$ the $\mathrm{Al} / \mathrm{Cac}-\mathrm{AMP}$ system partially precipitated, whereas at $\mathrm{pH}=7.0$ it remained in solution (Fig. 3 ESI).

Regarding ${ }^{31} \mathrm{P}-\mathrm{NMR}$ spectra, at $\mathrm{pH}=5.0$ the peak of AMP shifted in the presence of $\mathrm{Al} / \mathrm{Cac}$ (Fig. 4A ESI), suggesting an interaction with the phosphate group. At $\mathrm{pH}=7.0$ no significant variation in chemical shift was observed (Fig. 4B ESI); however, for both systems a decrease in the phosphorous band width was noticeable. Little chemical shift variation was observed for the ${ }^{1} \mathrm{H}$ peaks of the adenine (Fig. 4C,D ESI). Moreover, the small shift of the methylene groups adjacent to the phosphorous site $(\delta=3.97 \mathrm{ppm}$ at $\mathrm{pH}=7.0)$ could suggest an interaction with the phosphate group (Fig. 4D ESI). The ${ }^{27} \mathrm{Al}-\mathrm{NMR}$ spectra showed a broad peak around 50ppm for both $\mathrm{pH}$ values, advancing a similar structure for the aluminum system (Fig. 4E ESI) and a significant shift of the peak respect to the ${ }^{27} \mathrm{Al}-\mathrm{NMR}$ spectra of $\mathrm{Al} / \mathrm{Cac}(\delta=7.5 \mathrm{ppm})^{29}$, thus confirming metal ion binding to the nucleotide.

Kinetic experiments, where absorbance changes with time under aluminum excess were measured, showed a hypochromic effect of the adenosine band, agreeing with an interaction of $\mathrm{Al} / \mathrm{Cac}$ with AMP (Fig. $5 \mathrm{ESI}$ ). Interaction of aluminum forms with AMP and ATP is reported in the literature and the affinity has been claimed to be stronger compared to other metal ions. From the literature data, the interaction with phosphate group seems to be preferred, although interaction with adenine group has also been reported. ${ }^{35-37}$

\subsection{Binding of $\mathrm{Al} / \mathrm{Cac}$ to poly(rA) and poly(rU)}

UV titrations. Sample spectra for increasing $\mathrm{C}_{\mathrm{AICac}} / \mathrm{C}_{\mathrm{P}}$ ratios were recorded, under equilibrium conditions, at $\mathrm{pH}=5.0$ and $\mathrm{pH}=7.0$. The behaviour of the systems was complex and the titration curves were biphasic.

Concerning the double stranded poly(rA), at $\mathrm{pH}=5.0$, an initial small (but robust and reproducible) hyperchromic effect was visible for the $\mathrm{Al} / \mathrm{Cac}-[\mathrm{poly}(\mathrm{rA})]_{2}$ system, with a modest bathochromic effect of the maximum, from 252 to $254 \mathrm{~nm}$ (Fig. 1A). On the other hand, the interaction of $\mathrm{Al} / \mathrm{Cac}$ with poly $(\mathrm{rU})$ caused a decrease in absorbance (Fig. 1B). As for the second part of the experiments $\left(\mathrm{C}_{\mathrm{AICad}} / \mathrm{C}_{\mathrm{P}}\right.$ higher than 1.0 , for both systems), signal decrease was detected, which can be related to formation of a second adduct under conditions of aluminum excess. 

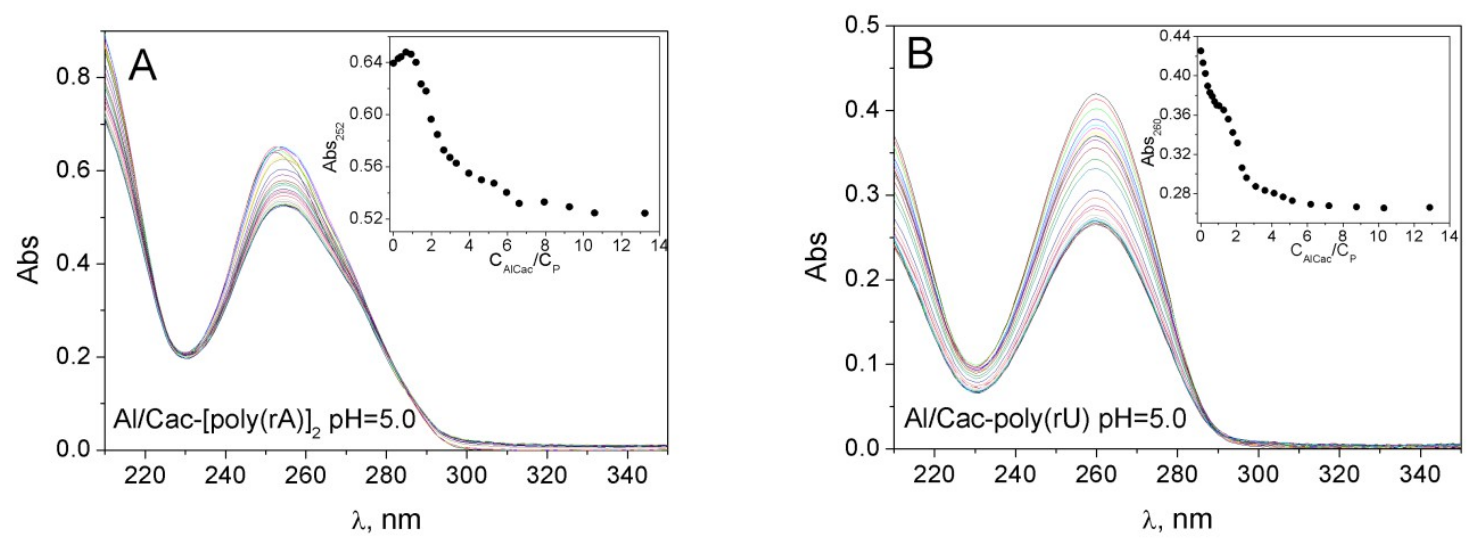

Fig. 1 Spectrophotometric titrations at $\mathrm{pH}=5.0$. (A) $\mathrm{Al} / \mathrm{Cac}-[\mathrm{poly}(\mathrm{rA})]_{2}, \mathrm{C}_{\mathrm{P}}=3.8 \times 10^{-5} \mathrm{M}$; inset: track at $252 \mathrm{~nm}$. (B) $\mathrm{Al} / \mathrm{Cac}-$ poly $(\mathrm{rU}), \mathrm{C}_{\mathrm{P}}=4.8 \times 10^{-5} \mathrm{M}$; inset: track at $260 \mathrm{~nm}$. $\mathrm{I}=0.1 \mathrm{M}\left(\mathrm{NaClO}_{4}\right)$ and $\mathrm{T}=25.0^{\circ} \mathrm{C}$.

Concerning the single-stranded poly(rA), at $\mathrm{pH} 7.0$, the interaction was even more complex. Actually, an initial hyperchromic effect was present and, under $\mathrm{Al} / \mathrm{Cac}$ excess, baseline increase and change of the spectrum shape were observed (Fig. 2A). The effect initially observed suggests metal interaction with the nitrogenous base for single-stranded poly(rA), which causes hyperchromism of the absorbance peak. ${ }^{38}$ Regarding the second effect, the enhanced scattering likely reflects an aggregation of the strands. Fig. 6 ESI compares the tracks at the maximum of absorbance (257 and $260 \mathrm{~nm}$ for poly(rA) and poly(rU), respectively) and at 320nm, showing a decrease in the absorbance maximum together with baseline enhancement. On the other hand, the interaction of $\mathrm{Al} / \mathrm{Cac}$ with poly $(\mathrm{rU})$ brought about signal lowering at low $\mathrm{C}_{\mathrm{AlCac}} / \mathrm{C}_{\mathrm{P}}$ values, and an aggregation effect at high $\mathrm{C}_{\mathrm{AlCac}} / \mathrm{C}_{\mathrm{P}}$ ratio (Fig. 2B).

Aggregation was observed by Kankia ${ }^{39}$ for poly(rA) in the presence of $\mathrm{Mg}^{2+}$, an effect that causes the baseline to increase and a hypochromic effect as well. For aluminum, the same effect was found for both poly(rA) and poly(rU). This implies that the aggregation is not promoted by a particular base pair, but rather it starts up when an adequate excess of aluminum complex is present $\left(\mathrm{C}_{\mathrm{AlCa}} / \mathrm{C}_{\mathrm{P}}\right.$ about 4.0 for both systems). Scattering will be carefully analyzed in the kinetic study (see below).
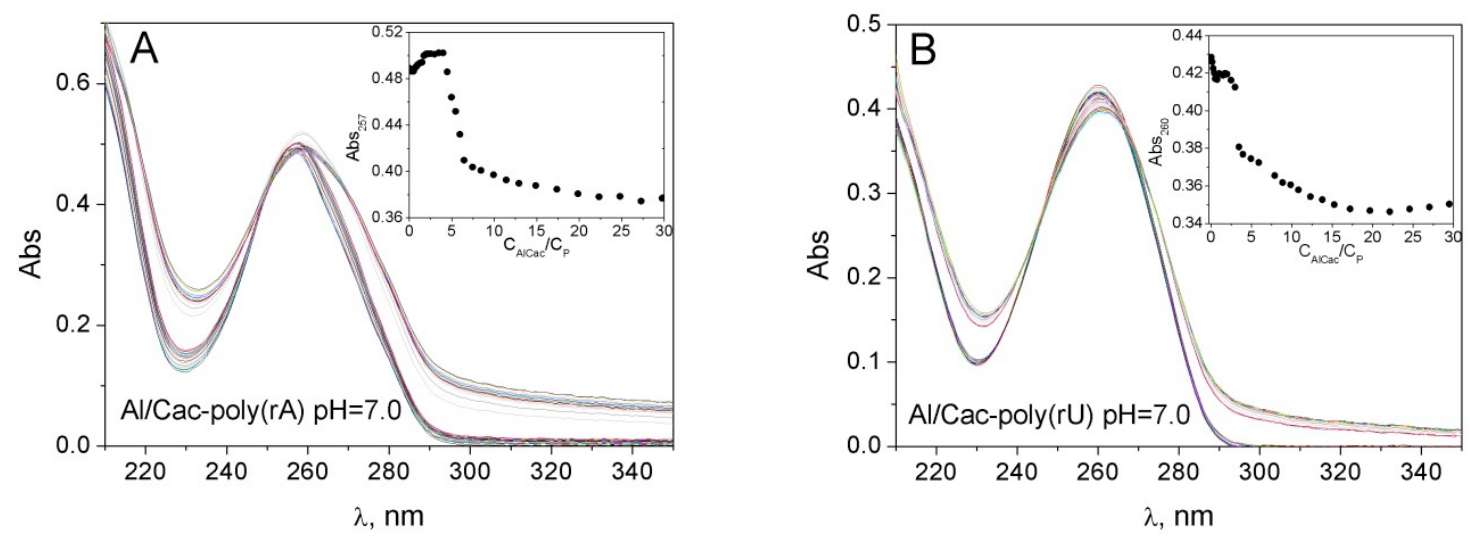

Fig. 2 Spectrophotometric titrations at $\mathrm{pH}=7.0$. (A) $\mathrm{Al} / \mathrm{Cac}-\mathrm{poly}(\mathrm{rA}), \mathrm{C}_{\mathrm{P}}=5.0 \times 10^{-5} \mathrm{M}$; inset: track at $257 \mathrm{~nm}$. (B) $\mathrm{Al} / \mathrm{Cac}-$ poly $(\mathrm{rU}), \mathrm{C}_{\mathrm{P}}=5.0 \times 10^{-5} \mathrm{M}$; inset: track at $260 \mathrm{~nm}$, the scattering value was subtracted from the maximum absorbance. $\mathrm{I}=0.1 \mathrm{M}\left(\mathrm{NaClO}_{4}\right)$, and $\mathrm{T}=25.0{ }^{\circ} \mathrm{C}$. 
Circular Dichroism. Al/Cac greatly affected the circular dichroism of poly(rA). At $\mathrm{pH}=5.0$ the interaction of aluminum/cacodylate with double-stranded [poly $(\mathrm{rA})]_{2}$ consisted of three different regions (Fig. 3A, inset): (1) for $\mathrm{C}_{\mathrm{AlCad}} / \mathrm{C}_{\mathrm{P}}<1.0$ a small decrease of the dichroic peak occurred. (2) RNA precipitated in the range $1.0<\mathrm{C}_{\mathrm{AlCac}} / \mathrm{C}_{\mathrm{P}}<10$, and the signal lowered down to zero. (3) In the presence of a high concentration of metal complex $\left(\mathrm{C}_{\mathrm{AlCa}} / \mathrm{C}_{\mathrm{P}}>10\right)$ the polynucleotide remained in solution. Concerning the Al/Cac-AMP system, precipitation was observed at $\mathrm{pH} 5$, as well (Fig. 3 ESI).

At $\mathrm{pH}=7.0$, addition of aluminum to poly(rA) caused a significant decrease in the $\mathrm{CD}$ signals (Fig. 3B). The effect observed concurs with the transition from the ordered poly(rA) structure to a random coil one. The unwinding of the single helix agrees with an interaction with the adenine, promoting unstacking of the bases. ${ }^{38}$ The further decrease of the band together with the shift of the minimum (from 248 to $251 \mathrm{~nm}$ ) and maximum (from 266 to $269 \mathrm{~nm}$ ) in $\mathrm{Al} / \mathrm{Cac}$ excess should be due to the aggregation effect observed in the UV experiments (Fig. 2A), also in agreement with the CD kinetic experiments.
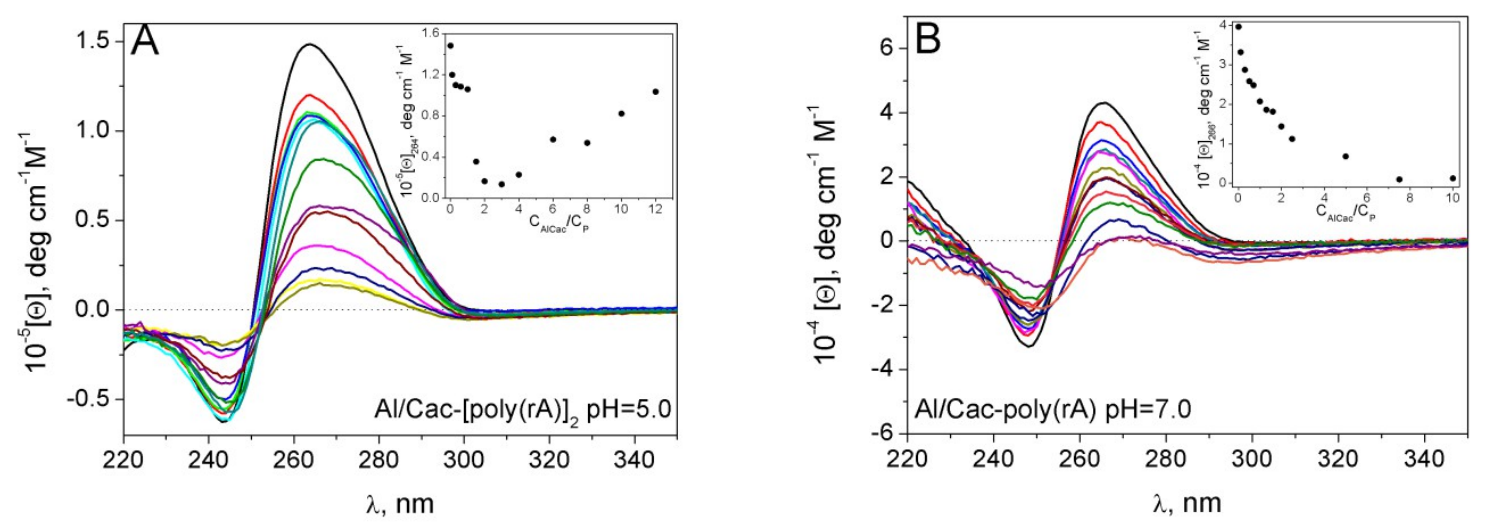

Fig. 3 CD spectra for increasing $\mathrm{C}_{\mathrm{AlCa}} / \mathrm{C}_{\mathrm{P}}$ ratio. (A) $\mathrm{Al} / \mathrm{Cac}-[\mathrm{poly}(\mathrm{rA})]_{2}$ at $\mathrm{pH}=5.0$; inset: track at $264 \mathrm{~nm}$. (B) $\mathrm{Al} / \mathrm{Cac}-$ poly $(\mathrm{rA})$ at $\mathrm{pH}=7.0$; inset: track at $266 \mathrm{~nm} . \mathrm{C}_{\mathrm{P}}=5.0 \times 10^{-5} \mathrm{M}, \mathrm{I}=0.1 \mathrm{M}\left(\mathrm{NaClO}_{4}\right)$ and $\mathrm{T}=25.0^{\circ} \mathrm{C}$.

The dichroic signal of poly(rU) is lower because of its random coil structure; however, a lowering in the signal was found to occur for the $\mathrm{Al} / \mathrm{Cac}-$ poly(rU) system under both $\mathrm{pH}$ conditions (Fig. $7 \mathrm{ESI}$ ).

Thermal Stability. Thermal denaturation experiments provided valuable information about the $\mathrm{Al} / \mathrm{Cac}$ effect on the polynucleotides stability.

At $\mathrm{pH}=5.0$, the hyperchromic effect, observed with $[\mathrm{poly}(\mathrm{rA})]_{2}$ under conditions of $\mathrm{Al} / \mathrm{Cac}$ defect, was due to the conversion of the double- to single-stranded poly(rA) (Fig. 4A). The presence of the aluminum-cacodylate complex caused the broadening of the melting sigmoid curve, concurring with enhancement of the inhomogeneity degree of the systems. No melting temperature values could be obtained because the absorbance did not reach a plateau. Broad sigmoid curves are observed for DNA in the presence of aluminum, as well. ${ }^{11}$ From the literature data, destabilization of the [poly(rA) $]_{2}$ double-helix is verified for the majority of metal ions. As the double-helix is stabilized by hydrogen bonds involving the phosphate and the nitrogenous groups, the interaction with such coordination sites promotes the transition to single-stranded 
RNA. ${ }^{38}$

In contrast, the presence of an excess of $\mathrm{Al} / \mathrm{Cac}$, results in a hypochromic effect (Fig. 4B). Such an observation reinforces the conclusions provided by the CD spectra, which suggested the formation of a further adduct whose stability is enhanced by increasing the metal to RNA ratio, as revealed by the rise of the melting temperature. Increasing the temperature resulted in a reduction of the extent of association.
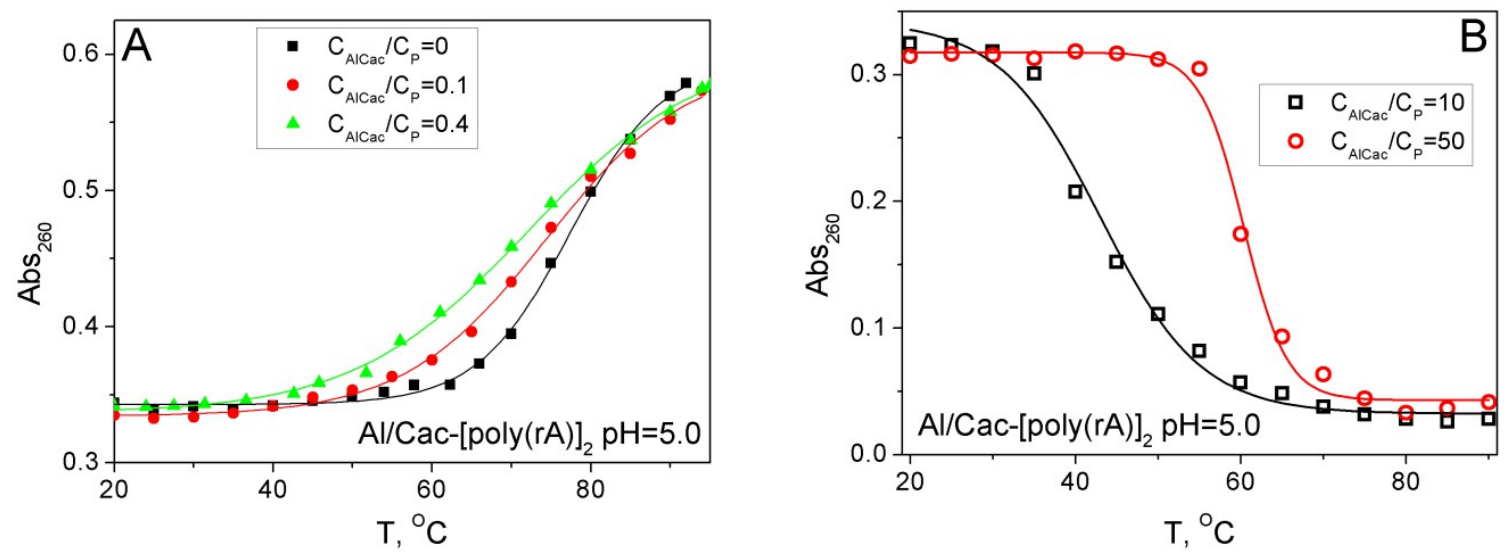

Fig. 4 Denaturation of $[\text { poly }(r A)]_{2}$ in defect $(A)$ and excess (B) of $A 1 / C a c . C_{P}=2.5 \times 10^{-5} \mathrm{M}, p H=5.0$ and $I=0.1 \mathrm{M}$ $\left(\mathrm{NaClO}_{4}\right)$.

Fig. 5 shows the denaturation of the $\mathrm{Al} / \mathrm{Cac}-\operatorname{poly}(\mathrm{rA})$ system at $\mathrm{pH}=7.0$. Since the absorbance value was the sum of the system absorption and the scattering of the solution caused by aggregation, the value of the latter had to be subtracted. The result was a sigmoidal hypochromic trend, ascribable to breakage of the aggregated form ${ }^{40}$ (Fig. 5A for Al/Cac-poly(rA) and Fig. 8A ESI for Al/Cac-poly(rU)). Rising the metal concentration, the melting temperature increased up to a plateau (Fig. 5B for $\mathrm{M}_{2} \mathrm{~L}_{2}$ poly(rA) and Fig. 8B ESI for $\mathrm{Al} / \mathrm{Cac}-$ poly(rU)). The resulting form probably was not the single-stranded one because the scattering was still present and the resulting absorbance was different.
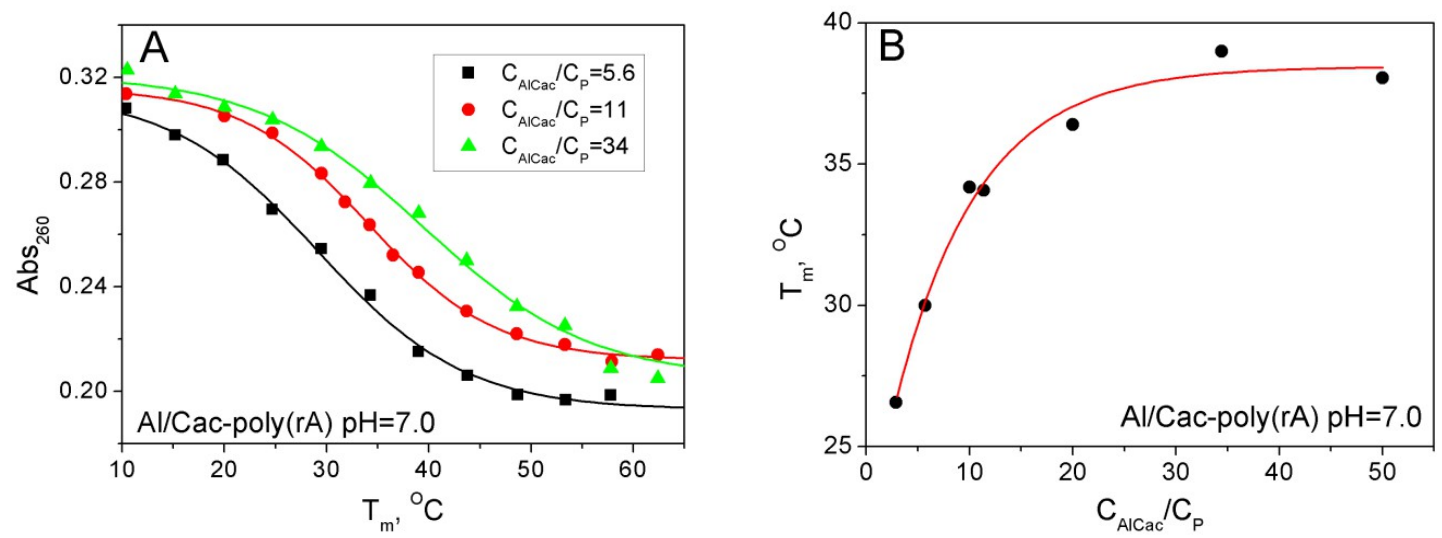

Fig. 5 Denaturation of the aggregated forms of Al/Cac-poly(rA). (A) Examples of melting curves. (B) Track of $\mathrm{T}_{\mathrm{m}}$ for different $\mathrm{C}_{\mathrm{AICa}} / \mathrm{C}_{\mathrm{P}}$ ratios. $\mathrm{C}_{\mathrm{P}}=3.4 \times 10^{-5} \mathrm{M}, \mathrm{I}=0.1 \mathrm{M}\left(\mathrm{NaClO}_{4}\right)$ and $\mathrm{pH}=7.0$.

Viscometry. The viscosity values decreased for all the investigated systems upon increasing the metal/cacodylate complex content (Fig. 6). Precipitation of doublestranded $[\mathrm{poly}(\mathrm{rA})]_{2}$ occurred at $\mathrm{C}_{\mathrm{AlCac}} / \mathrm{C}_{\mathrm{P}}=1.0$ ratio. The large viscosity variation 
observed for poly(rA) and poly(rU) implies major structural changes. Actually, the unwinding of the partially ordered structure of poly(rA) provokes a viscosity decrease. $^{41}$ On the other hand, the higher variation of viscosity of poly(rU) is noteworthy because this polymer displays a random coil structure even in the absence of metal ions. Viscosity decrease is reported for poly(rU) with temperature decrease and in the presence of various salts. ${ }^{42,43}$ The observed behaviour has been ascribed to folding of the single-strand to form intramolecular double-helix. Similar explanation can be forwarded about the behaviour of $\mathrm{Al} / \mathrm{Cac}-$ poly $(\mathrm{rU})$, in agreement also with the observed decrease of the system absorbance (Fig. 1B and 2B) which, as the temperature decreases, is converted to a more ordered and compact form.

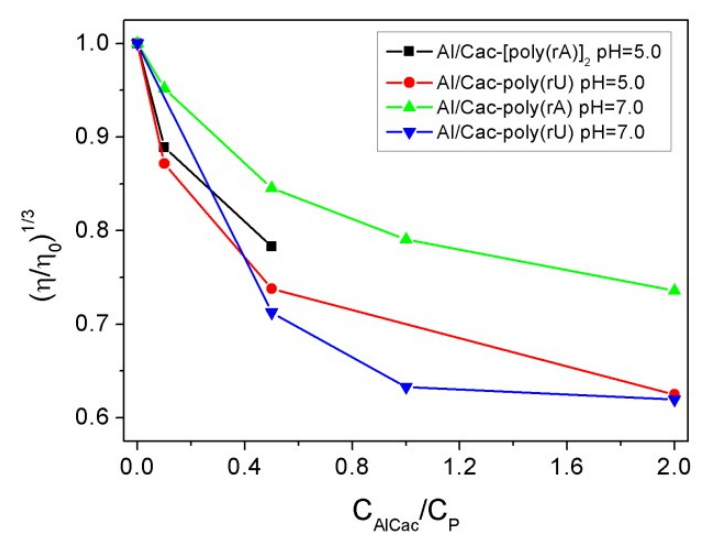

Fig. 6 Viscometric results for $\mathrm{Al} / \mathrm{Cac}-\mathrm{RNA}$ systems at different $\mathrm{C}_{\mathrm{AlCac}} / \mathrm{C}_{\mathrm{P}} . \mathrm{C}_{\mathrm{P}}=2.0 \mathrm{x} 10^{-4} \mathrm{M}, \mathrm{I}=0.1 \mathrm{M}\left(\mathrm{NaClO}_{4}\right)$ and $\mathrm{T}=25.0$ ${ }^{\circ} \mathrm{C}$.

Kinetics: Al/Cac-RNA complex formation. The kinetic aspects of the reactions between $\mathrm{Al} / \mathrm{Cac}$ and the RNAs were investigated by recording the variation of the absorbance with time. Examples of the obtained kinetic curves are shown in Figure 7. A hyperchromic signal was visible for poly(rA) (Fig. 7A and 7C), whereas for poly(rU) a hypochromic effect (Fig. 7B and 7D) was observed under both $\mathrm{pH}$ conditions.
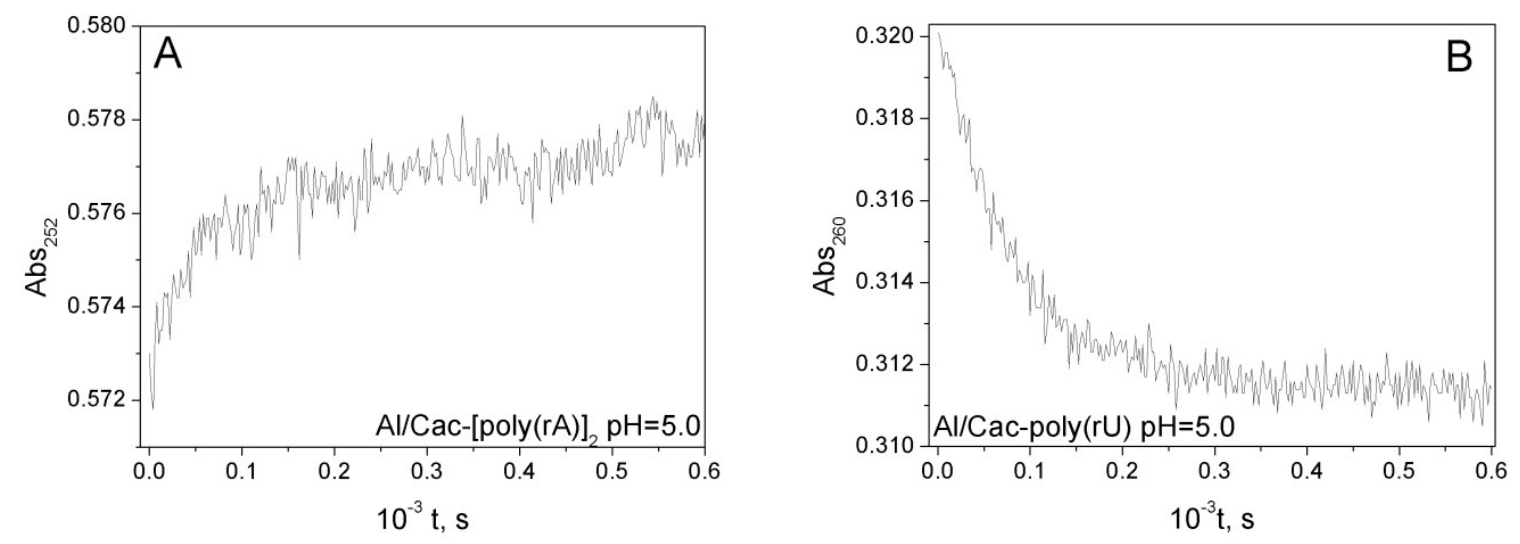

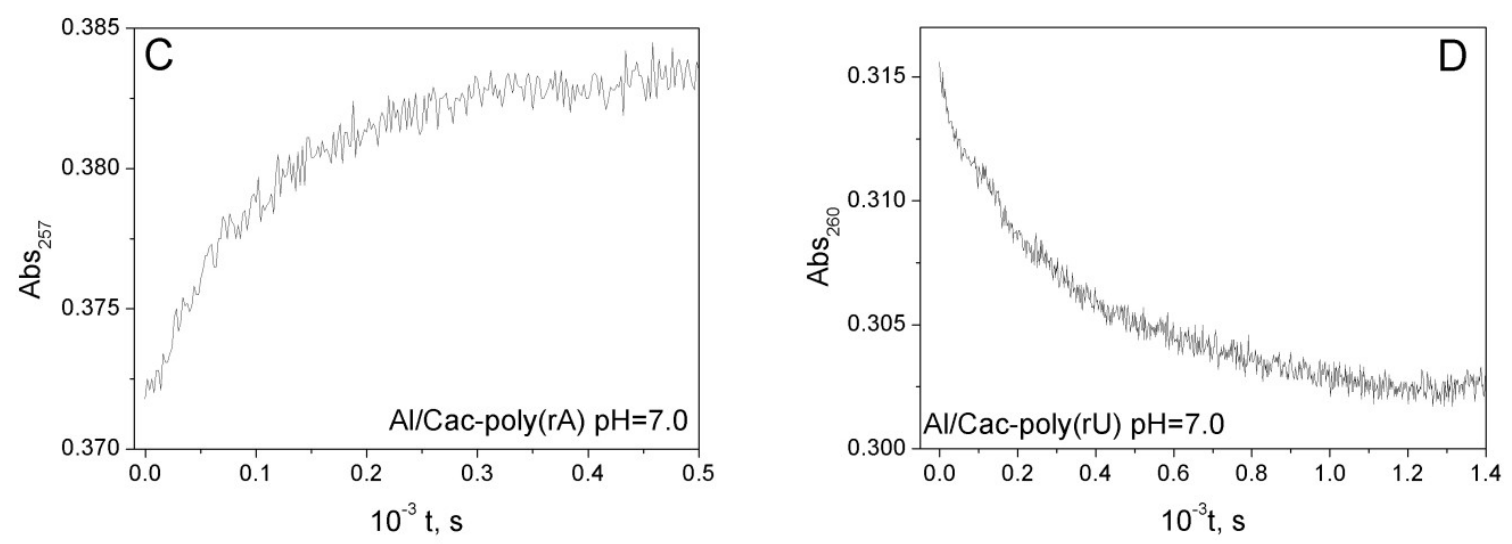

Fig. 7 Kinetic traces for the interaction between $\mathrm{Al} / \mathrm{Cac}$ and RNA: (A) $[\mathrm{poly}(\mathrm{rA})]_{2}$ at $\mathrm{pH}=5.0$, track at $252 \mathrm{~nm}$. (B) poly(rU) at $\mathrm{pH}=5.0$, track at $260 \mathrm{~nm}$. (C) poly(rA) at $\mathrm{pH}=7.0$, track at $257 \mathrm{~nm}$. (D) poly(rU) at $\mathrm{pH}=7.0$, track at $260 \mathrm{~nm}$. $\mathrm{C}_{\mathrm{P}}=3.4 \times 10^{-5} \mathrm{M}, \mathrm{C}_{\mathrm{AlCac}}=4.1 \times 10^{-4} \mathrm{M}, \mathrm{I}=0.1 \mathrm{M}\left(\mathrm{NaClO}_{4}\right)$ and $\mathrm{T}=25.0^{\circ} \mathrm{C}$.

The reaction order with respect to each reactant was derived from the slope of dilogarithmic plots of the initial rate $\mathrm{v}_{\mathrm{i}}$ versus the molar concentration $\mathrm{C}_{\mathrm{i}}$ of the $i$-th reactant by means of Equation (2), $\mathrm{k}^{\prime}$ being a constant.

The individual reaction orders are listed in Table 1 (see Supporting Information, Figs. 9 ESI-12 ESI for details). For the experiments at variable concentration aluminum, the concentration of cacodylate also needed to be varied in order to maintain $\mathrm{C}_{\mathrm{L}} / \mathrm{C}_{\mathrm{Al}}=5.0$. Thus, the sum of the individual reaction orders with respect to metal containing species and free cacodylate $\left(\mathrm{n}_{\mathrm{AlCac}}\right.$ and $\left.\mathrm{n}_{\mathrm{L}}\right)$, was obtained. Being $\mathrm{n}_{\mathrm{L}}$ known, the value of $n_{\text {AICac }}$ could be obtained straightforwardly.

Table 1 Reaction orders $\mathrm{n}_{\mathrm{i}}$ of the reactants for the reaction between $\mathrm{Al} / \mathrm{Cac}$ and RNA. $\mathrm{I}=0.1 \mathrm{M}$, and $\mathrm{T}=25.0^{\circ} \mathrm{C}$.

\begin{tabular}{lccc}
\hline & $\mathbf{n}_{\text {AICac }}$ & $\mathbf{n}_{\mathbf{L}}$ & $\mathbf{n}_{\mathbf{P}}$ \\
\hline $\begin{array}{l}{[\text { poly(rA) }]_{2}} \\
\text { pH=5.0 }\end{array}$ & 1.2 & -1.2 & 0.9 \\
poly(rU) pH=5.0 & 1.0 & -2.0 & \\
poly(rA) pH=7.0 & 2.0 & -2.0 & 1.0 \\
poly(rU) pH=7.0 & 2.1 & -2.1 & 1.0 \\
\hline
\end{tabular}

The negative reaction order with respect to cacodylate $\left(\mathrm{n}_{\mathrm{L}}=-2\right)$ at both $\mathrm{pH} 5.0$ and 7.0 indicates that, under the experimental conditions employed, the main species present in solution is the $\mathrm{M}_{2} \mathrm{~L}_{2}$ dimer, which is unreactive. Dissociation of cacodylate from the aluminum/cacodylate complex is needed to give simpler species able to interact with RNAs. $\mathrm{M}_{2} \mathrm{~L}_{2}$ dissociation is reported in Reactions (3) and (4), where $\mathrm{K}_{2}$ and $\mathrm{K}_{1}$ are the apparent constants of the aluminum/cacodylate complex formation at $\mathrm{pH}=5.0$. Note that Reaction (4) involves the formation of two Al(III) ions instead of the $\mathrm{M}_{2}$ because free dimeric aluminum was negligible under the working conditions. ${ }^{9}$ On the other hand, $\mathrm{M}_{2} \mathrm{~L}$ formation was observed in our previous work. ${ }^{29}$

Concerning $\mathrm{Al} / \mathrm{Cac}-\mathrm{poly}(\mathrm{rU})$ at $\mathrm{pH}=5.0$, the reaction orders concur with a model 
(Equation (5)) where two molecules of cacodylate are released upon interaction of the metal complex with the monomeric unit of RNA (see mechanism in Appendix I, ESI). In Equation (5), $k_{1}$ is the forward kinetic constant for the metal-RNA complex formation.

According to this model the initial rate $\mathrm{v}_{i}$ is given by Equation (6)

Two monomeric aluminum ions, from Reaction (4), would interact with the polymer, whereas the $\mathrm{M}_{2} \mathrm{~L}$ and $\mathrm{M}_{2} \mathrm{~L}_{2}$ species do not react directly. The kinetic parameters of the reaction were evaluated from the intercept of the dilogarithmic plots. The values for $\mathrm{k}_{1}$ obtained from each graph of the initial rates are in good agreement with each other (Table 1 ESI, $\mathrm{k}_{1} /\left(2 \mathrm{~K}_{1} \mathrm{~K}_{2}\right)=(7.6 \pm 0.6) \times 10^{-5} \mathrm{~s}^{-1} \mathrm{M}^{2}$, Confidence $\left.95 \%\right)$, reinforcing the goodness of our hypothesis.

For the $\mathrm{Al} / \mathrm{Cac}-$ poly(rA) and $\mathrm{Al} / \mathrm{Cac}-$ poly(rU) systems at $\mathrm{pH}=7.0$ the partial reaction orders are quite similar, suggesting a similar kinetic mechanism. However, these are significantly different respect to the above cited mechanism found for poly(rU) at $\mathrm{pH}=5.0$. At $\mathrm{pH}=7.0$ the reaction mechanism for both RNAs should involve two $\mathrm{M}_{2} \mathrm{~L}$ complexes originated from Reaction (3) (Appendix II, ESI); under these circumstances the reaction is expressed by Equation (7) and the rate law by Equation (8) $\left(\mathrm{k}_{2} /\left(4 \mathrm{~K}_{1}^{\prime}{ }^{2}\right)=0.24 \pm 0.10 \mathrm{~s}^{-1} \mathrm{M}^{2}\right.$ for $\mathrm{Al} / \mathrm{Cac}$-poly $(\mathrm{rA})$ and $\mathrm{k}_{2}^{\prime} /\left(4 \mathrm{~K}_{1}^{\prime}{ }^{2}\right)=0.12 \pm 0.01 \mathrm{~s}^{-1} \mathrm{M}^{2}$ for $\mathrm{Al} / \mathrm{Cac}-$ poly(rU), where $\mathrm{K}_{2}^{\prime}$ refers to Reaction (3) at $\mathrm{pH}=7.0$ and $\mathrm{k}_{2}^{\prime}$ to poly(rU)).

The difference in the reaction mechanism between poly(rU) at $\mathrm{pH} 5.0$ and 7.0 is interesting. In the first case, two aquo-ions of $\mathrm{M}$ are supposed to interact with the polynucleotide, whereas in the latter case two molecules of $\mathrm{M}_{2} \mathrm{~L}$ react with the monomeric RNA units. This could be explained by the fact that at $\mathrm{pH}=5.0$ the cacodylate species is more than $90 \%$ protonated $\left(\mathrm{pK}_{\mathrm{A}}=6.2\right)^{29}$ and it is a general rule that protonation of the ligand favours its release.

To conclude, concerning $[\operatorname{poly}(\mathrm{rA})]_{2}$ at $\mathrm{pH}=5.0$, the reaction mechanism is given by Equation (9) and the relevant initial rate equation is given by Equation (10) $\left(\mathrm{k}_{3} /\right.$ $\left(2 \mathrm{~K}_{1}\right)=(5.0 \pm 2.5) \times 10^{-2} \mathrm{~s}^{-1} \mathrm{M}$, Appendix III, ESI). The change of the order of reaction with respect to the ligand implies a change in the reaction mechanism: here, instead of two free $\mathrm{Al}$ (III) ions, one molecule of $\mathrm{M}_{2} \mathrm{~L}$ interacts with a polynucleotide base pair.

The fact that only one molecule interacts with $[\operatorname{poly}(\mathrm{rA})]_{2}$, whereas for two molecules react with poly $(\mathrm{rA})$, is remarkable. Actually, adenine is partially protonated at $\mathrm{pH}=5.0$ and it could inhibit the income of a second molecule of $\mathrm{M}_{2} \mathrm{~L}$. The results of the $\mathrm{Al} / \mathrm{Cac}-\mathrm{AMP}{ }^{31} \mathrm{P}-\mathrm{NMR}$ spectrum at $\mathrm{pH}=5.0$ (Fig. 4A ESI) suggest that in the binding of $\mathrm{Al} / \mathrm{Cac}$ to $[\mathrm{poly}(\mathrm{rA})]_{2}$ the phosphate plays the main role.

Kinetics: Aggregation Reaction. In addition to the effect discussed above, a further kinetic effect was displayed at $\mathrm{pH}=7.0$ by the investigated systems (Fig. 8). Actually, 
an increase in the signal was detected, which was ascribable to the previously observed aggregation effect at this $\mathrm{pH}$ (Fig. 2).
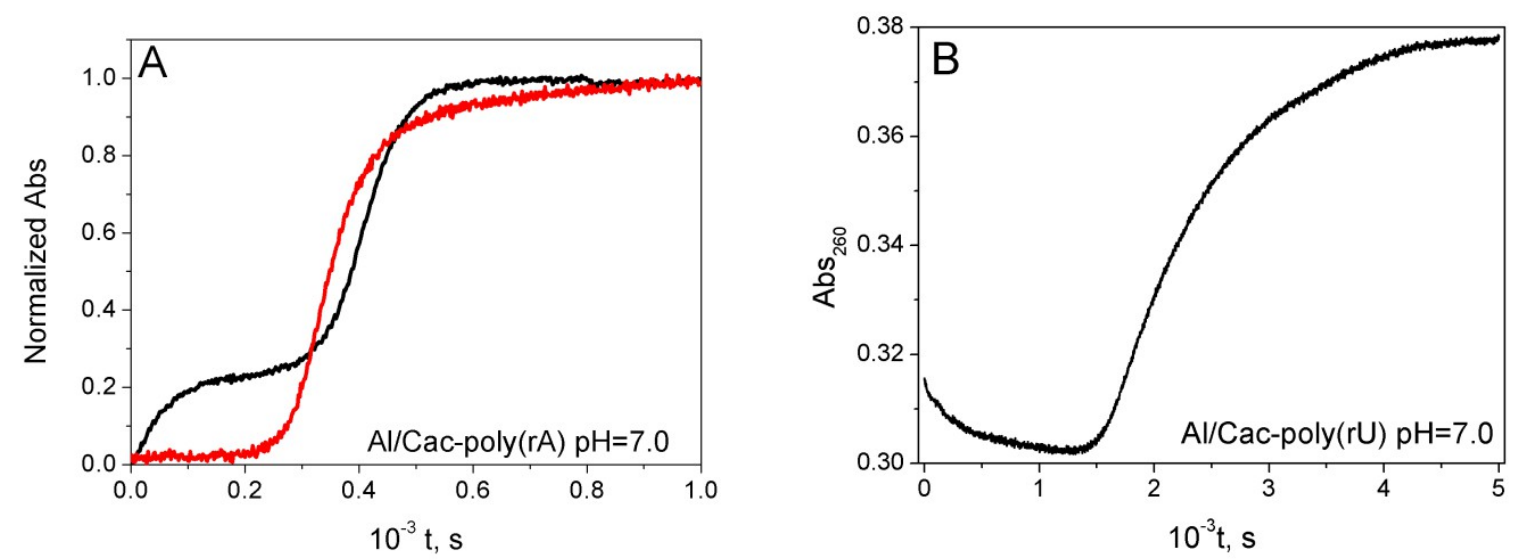

Fig. 8 Kinetic traces of the reaction between $\mathrm{Al} / \mathrm{Cac}$ and RNA and subsequent aggregation process. (A) Comparison of the normalized kinetic curves at 257 (black line) and 320nm (red line) for Al/Cac-poly(rA); (B) Al/Cac-poly(rU), track at $260 \mathrm{~nm} . \mathrm{C}_{\mathrm{P}}=3.4 \times 10^{-5} \mathrm{M}, \mathrm{C}_{\mathrm{AlCac}}=4.1 \times 10^{-4} \mathrm{M}, \mathrm{I}=0.1 \mathrm{M}\left(\mathrm{NaClO}_{4}\right), \mathrm{pH}=7.0$ and $\mathrm{T}=25.0{ }^{\circ} \mathrm{C}$.

Comparison of the kinetic curves recorded at the maximum of absorption of the polynucleotides and at $\lambda=320 \mathrm{~nm}$, where any RNA absorption is absent, revealed hyperchromic effects in both kinetic curves (Fig. 8A). Consequently, the second absorbance enhancement was related to aggregation of the polynucleotides chains, which reflected in an increase of the light scattering process.

The same effect was clearly visible for the CD signals. In this case, the aggregation caused a signal decrease with time (Fig. 9).
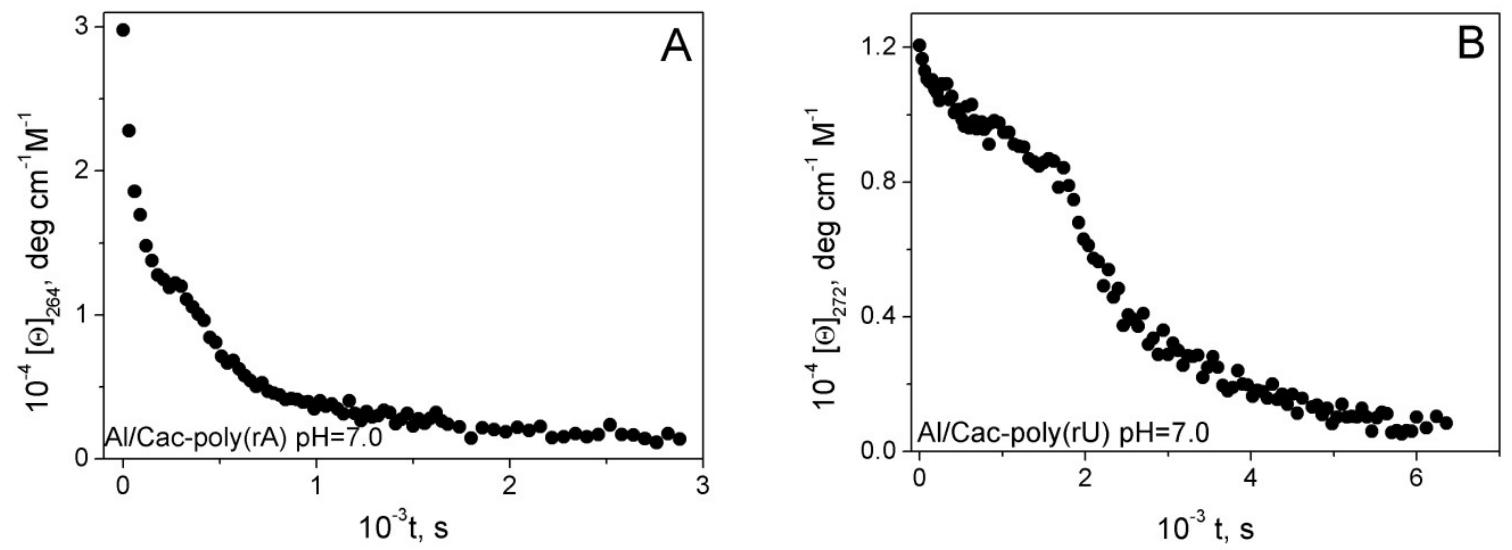

Fig. 9 Kinetics of the dichroic signal under $\mathrm{Al} / \mathrm{Cac}$ excess. (A) $\mathrm{Al} / \mathrm{Cac}-$ poly(rA), track at $264 \mathrm{~nm}$. (B) $\mathrm{Al} / \mathrm{Cac}-$ poly(rU), track at $272 \mathrm{~nm} . \mathrm{C}_{\mathrm{P}}=5.0 \times 10^{-5} \mathrm{M}, \mathrm{C}_{\mathrm{AlCac}}=7.5 \times 10^{-4} \mathrm{M}, \mathrm{I}=0.1 \mathrm{M}\left(\mathrm{NaClO}_{4}\right), \mathrm{pH}=7.0$ and $\mathrm{T}=25.0^{\circ} \mathrm{C}$.

The slow kinetic curves were acquired for different concentration of $\mathrm{Al} / \mathrm{Cac}$, free ligand and RNA. Figure 10 shows some sets of kinetic curves concerning the Al/Cacpoly(rA) system, recorded at $257 \mathrm{~nm}$. 

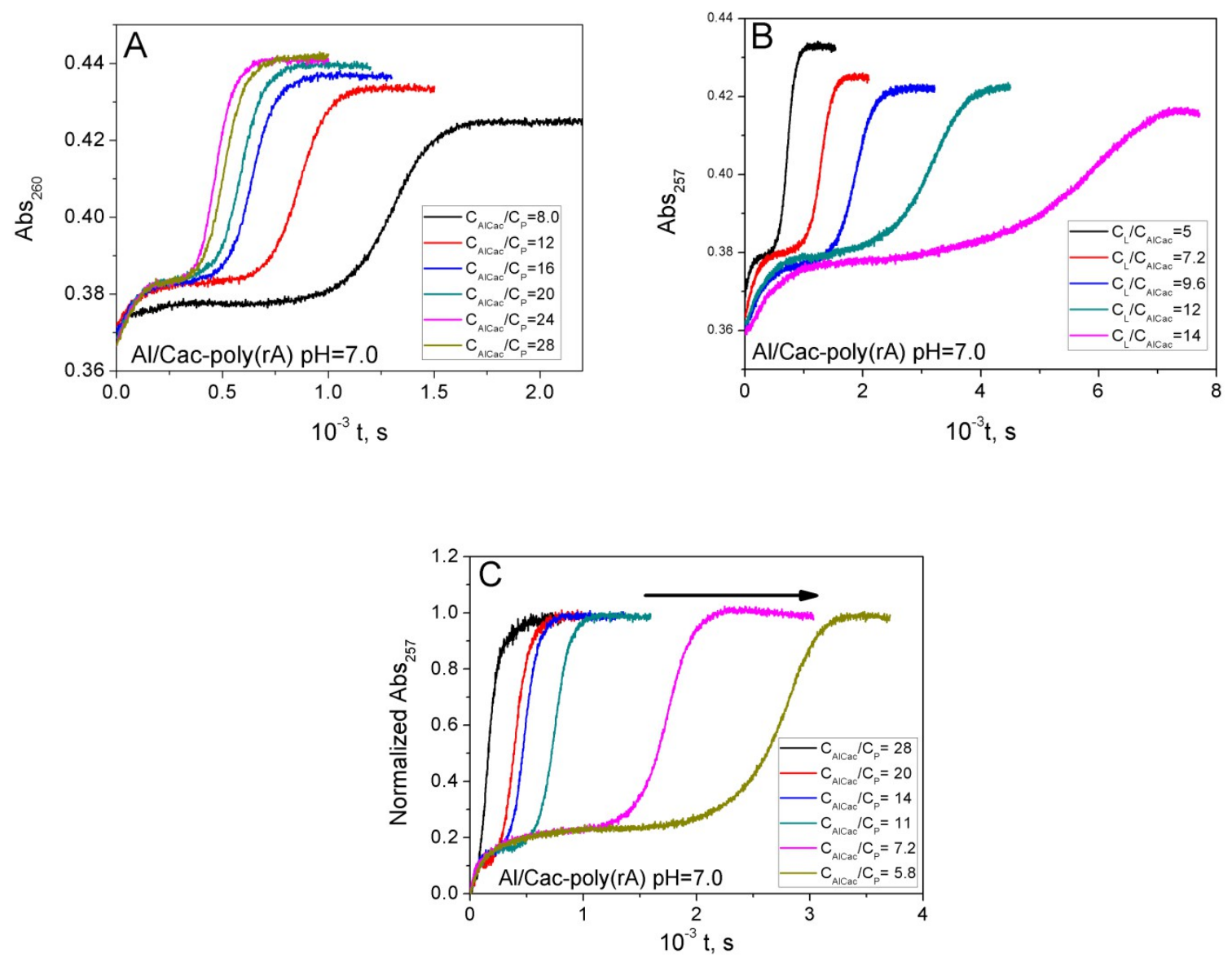

Fig. 10 Kinetic curves at $\lambda=257 \mathrm{~nm}$ of $\mathrm{Al} / \mathrm{Cac}-\operatorname{poly}(\mathrm{rA})$; (A) different $\mathrm{C}_{\mathrm{AlCa}}, \mathrm{C}_{\mathrm{P}}=3.4 \times 10^{-5} \mathrm{M}$; (B) different $\mathrm{C}_{\mathrm{L}}$, $\mathrm{C}_{\mathrm{P}}=3.4 \times 10^{-5} \mathrm{M}(\mathrm{C})$ different $\mathrm{C}_{\mathrm{P}}$ (normalized absorbance values), $\mathrm{C}_{\mathrm{AlCac}}=4.1 \times 10^{-4} \mathrm{M}$. $\mathrm{I}=0.1 \mathrm{M}\left(\mathrm{NaClO}_{4}\right), \mathrm{pH}=7.0$ and $\mathrm{T}=25.0^{\circ} \mathrm{C}$.

From Figs. 10A-C it was possible to obtain a qualitative trend about the contribution of each reactant to the aggregation effect. By increasing the amount of $\mathrm{Al} / \mathrm{Cac}$, the aggregation was faster (Fig. 10A), whereas free cacodylate and RNA concentration slowed down the kinetic rate (Fig. 10B,C). The aggregation kinetics were studied by means of the Avrami equation, ${ }^{44-46}$ successfully applied to polymeric systems. ${ }^{47}$ The absorbance versus time kinetic curves were fitted by Equation (11),

where $\mathrm{A}$ is the curve amplitude, $\mathrm{B}$ the time constant and $\mathrm{m}$ a parameter that reflects the cooperativity of the aggregation process. From Equation (11) the $t_{1 / 2}$ parameter could be calculated as $\left.t_{1 / 2}=(\ln 2 / B)\right)^{1 / m} \cdot{ }^{47}$ Note that the start of the sigmoid curve was taken at the end of the first kinetic effect, subtracting in Equation (11) the $t_{0}$ value from $t_{\text {read }}$, being $t=t_{\text {read }}-t_{0}$. The analysis of the sigmoid curve was carried out at different concentrations of the metal complex and polynucleotide and the results are reported in Table 2 ESI and 3 ESI.

Firstly, for poly(rA), it was seen that the amplitude was enhanced by increasing $\mathrm{C}_{\mathrm{AlCac}}$ and $\mathrm{C}_{\mathrm{P}}$, whereas $\mathrm{t}_{1 / 2}$ decreased with $\mathrm{Al} / \mathrm{Cac}$ concentration (Fig. 10A) but it increased with $C_{P}$ (Fig. 10C). At first sight, these results could suggest (wrongly) that the RNA concentration diminishes the reaction rate. However, an increase in $C_{P}$ causes lowering of the $\mathrm{C}_{\mathrm{AlCa}} / \mathrm{C}_{\mathrm{P}}$ ratio, which affects the aggregation. On the other hand, the 
parameter $\mathrm{m}$, seems to depend on the RNA concentration ( $\mathrm{m}$ increased with $\mathrm{C}_{\mathrm{P}}$ up to $\mathrm{m}=4$ ), but not on the $\mathrm{Al} / \mathrm{Cac}$ concentration (Table $2 \mathrm{ESI}$ ).

$\mathrm{Al} /$ Cac-poly(rU) behaves similarly as the amplitude and $\mathrm{t}_{1 / 2}$ trends (Table $3 \mathrm{ESI}$ ). However, the $m$ value did not rise with $\mathrm{C}_{\mathrm{AlCac}}$ and $\mathrm{C}_{\mathrm{P}}$, being confined between 1.5 and 2.

The difference in $m$ values is noteworthy. It means that, even if the aluminum ion plays a principal role in the aggregation processes of both RNAs, the mechanisms follow different pathways, which depend on the nature of the nucleic acids. Such a difference can be related to the RNA secondary structure. Our results agree with the picture that the more ordered poly(rA) is able to develop an aggregation mechanism characterized by a higher degree of cooperativity and efficiency, as shown by the higher $\mathrm{m}$ and lower $\mathrm{t}_{1 / 2}$ values.

\section{Conclusions}

Aluminum strongly binds to single-stranded poly(rA) and poly(rU) in acidic and neutral $\mathrm{pH}$, interacting with the phosphate and the nitrogenous groups and inducing a notable alteration of the polynucleotides secondary structure. However, only the interaction with phosphate seems to be effective in the case of double-stranded $[\text { poly }(\mathrm{rA})]_{2}$. Kinetic studies indicate that cacodylate inhibits the interaction with RNA, although it favours aluminum to remain in solution. An aggregation effect process manifested itself at neutral $\mathrm{pH}$, which started by an excess of aluminum complex. The kinetic studies confirm that the ordered poly(rA) structure undergoes aggregation at a faster rate and with a higher cooperativity degree than poly(rU), which displays a random coil structure. The ability of aluminum to stabilize multiple nucleic acid strands could be of interest for the study of non-conventional forms of polynucleotides.

\section{Acknowledgements}

This work was supported by Obra Social "la Caixa" (OSLC-2012-007), MINECO, (CTQ2014-58812-C2-2-R, FEDER Funds) and Junta de Castilla y Leon (BU042U16), Spain.

\section{Notes and References}

1 S. A. Kazakov and S. M. Hecht, Encycl. Inorg. Bioinorg. Chem., 2006, 1-34.

2 R. K. O. Sigel and H. Sigel, Acc. Chem. Res., 2010, 43 (7), 974-978.

3 H. Diebler, F. Secco and M. Venturini, Biophys. Chem., 1987, 26 (2-3), 193205.

4 G. Luck and C. Zimmer, FEBS J., 1972, 29 (3), 528-536.

5 J. G. Duguid, V. A. Bloomfield, J. M. Benevides and G. J. Thomas, Biophys J., 1995, 69 (6), 2623-2641.

6 M. Langlais, H. A. Tajmir-Riahi and R. Savoie, Biopolymers, 1990, 30 (7-8), 743

$-752$.

7 G. L. Eichhorn and P. Clark, Proc. Natl. Acad. Sci. U. S. A., 1965, 53 (3), 586 
$-593$.

8 T. Biver, Coord. Chem. Rev., 2013, 257, 2765-2783.

9 C. F. Jr. Baes and R. E. Mesmer, The Hydrolysis of Cations, 1976, Wiley, New York, 112-123.

10 S. J. Karlik, G. L. Eichhorn, P. N. Lewis and D. R. Crapper, Biochemistry, 1980 ,

19 (26), 5991-5998.

11 S. J. Karlik and G. L. Eichhorn, J. Inorg. Biochem., 1989, 37 (4), 259-269.

12 A. T. Sarpola, V. K. Hietapelto, J. E. Jalonen, J. Jokela and J. H. Rämö, Int. J. Environ. Anal. Chem., 2006, 86 (13), 1007-1018.

13 S. P. Fricker, Dalton Trans., 2007, (43), 4903-4917.

14 P. Nayak, Environ. Res., 2002, 89 (2), 101-115.

15 M. A. Rogers and D. G. Simon, Age Ageing, 1999, 28 (2), 205-209.

16 R. J. Mailloux, J. Lemire and V. D. Appanna, Exp. Cell Res., 2011, 317 (16), 2231-2238.

17 S. Mahieu and M. L. Calvo, Toxicol. Lett., 1998, 94 (1), 47-56.

18 H. Jeffery, K. Abreo, E. Burgess, J. Cannata and J.L. Greger, J. Toxicol. Environ.

Health, Part A, 1996, 48 (6), 649-666.

19 V. Rondeau, D. Commenges, H. Jacqmin-Gadda and J. F. Dartigues, Am. J. Epidemiol., 2000, 152 (1), 59-66.

20 E. Gauthier, I. Fortier, F. Courchesne, P. Pepin, J. Mortimer and D. Gauvreau, Environ. Res., 2000, 84 (3), 234-246.

21 M. W. Bourassa and L. M. Miller, Metallomics, 2012, 4 (8), 721-738.

22 K. G. McGrath, Eur. J. Cancer Prev., 2003, 12 (6), 479-485.

23 P. D. Darbre, F. Mannello and C. Exley, J. Inorg. Biochem., 2013, 128, 257 -261 .

24 S. J. Mandriota, EBioMedicine, 2017, doi: 10.1016/j.ebiom.2017.06.025.

25 E. Furia, T. Marino and N. Russo, Dalton Trans., 2014, 43 (19), 7269-7274.

26 S. J. Karlik, E. Tarien, G. A. Elgavish and G. L. Eichhorn, Inorg. Chem., 1983,22

(3), 525-529.

27 W. R. Harris, G. Berthon, J. P. Day, C. Exley, T. P. Flaten, W. F. Forbes, T. Kiss, C. 568.

28 C. Exley and D. J. Birchall, J. Theor. Biol., 1992, 159 (1), 83-98.

29 M. Lari, H. J. Lozano, N. Busto, T. Biver, J. M. Leal, S. Ibeas, J. A. Platts, F. Secco

and B. García, Phys. Chem. Chem. Phys., 2015, 17 (44), 29803-29813.

30 J. R. Fresco and P. Doty, J. Am. Chem. Soc., 1957, 79 (14), 3928-3929.

31 T. N. Holcomb and I. Tinoco, Biopolymers, 1965, 3 (2), 121-133.

32 K. Imahori and K. Watanabe, Journal of Polymer Science: Polymer Symposia, Wiley Subscription Services, Inc., A Wiley Company, 1970, Vol. 30, pp. 633- 
656.

33 G. Cohen and H. Eisenberg, Biopolymers, 1969, 8 (1), 45-55.

34 A. Amirbahman, M. Gfeller and G. Furrer, Geochim. Cosmochim. Acta, 2000, 64 (5), 911-919.

35 T. Kiss, P. Zatta, and B. Corain, Coord. Chem. Rev., 1996, 149, 329-346.

36 T. Kiss, I. Sovago and R. B. Martin, Inorg. Chem., 1991, 30 (9), 2130-2132.

37 S. J. Karlik, G. A. Elgavish, G. L. Eichhorn, J. Am. Chem. Soc., 1983, 105 (3),

602 $-609$.

38 Y. A. Shin, J. M. Heim and G. L. Eichhorn, Bioinorg. Chem., 1972, 1 (2), 149 $-163$.

39 B. I. Kankia, Biophys. Chem., 2003, 104 (3), 643-654.

40 T. Biver, N. Busto, B. García, J. M. Leal, L. Menichetti, F. Secco, and M. Venturini, J. Inorg. Biochem., 2015, 151, 115-122.

41 H. Eisenberg and G. Felsenfeld, J. Mol. Biol., 1967, 30 (1), 17-37.

42 M. N. Lipsett, Proc. Natl. Acad. Sci. U. S. A., 1960, 46 (4), 445-446.

43 D. Bode, M. Heinecke and U. Schernau, Biochem. Biophys. Res. Commun., 1973, 52 (4), 1234-1240.

44 M. Avrami, J. Chem. Phys., 1939, 7 (12), 1103-1112.

45 M. Avrami, J. Chem. Phys., 1940, 8 (2), 212-224.

46 M. Avrami, J. Chem. Phys., 1941, 9 (2), 177-184.

47 M. Kodaka, Biophys. Chem., 2004, 107 (3), 243-253. 